\title{
The Impact of Fiscal Policy on Foreign Direct Investment Inflows: A Study of India and Select Asian Economies \\ Niti Bhasin
}

\begin{abstract}
While the role of taxation in influencing FDI has received considerable attention in literature, there has been very less work on examining the role of fiscal policy as a whole on FDI inflows. The dimension of fiscal policy that relates to the expenditure of the government has not received much attention in terms of its impact on FDI. This study would attempt to bridge the gap in literature by examining the impact of both the revenue and expenditure side of fiscal policy on FDI inflows in India and other select economies of the Asian region. The paper identifies the determinants of FDI flows with special reference to fiscal policy variables, namely tax treaties and developmental expenditure of the government. With the help of principle component regression, we have estimated a panel equation with the Least Squared Dummy Variables (fixed effects model) approach. The determinants which have emerged as significant are FDI openness and infrastructure. Our variables of interest, that is, the fiscal policy variables turn out to be insignificant. Thus while a competitive fiscal policy may facilitate operations of business, it is still not a prime consideration in investment decisions.
\end{abstract}

Keywords: Fiscal policy, Foreign direct investment, tax treaties.

\subsection{Introduction}

The beginning of the twenty first century marked a tremendous growth of international investments and trade along with the integration and openness of international markets. Foreign direct investment (FDI), in most part, is now made by multinational corporations (MNCs). Clearly, these MNCs play a major role in world trade and investments because of their demonstrated management skills, technology, financial resources and related advantages.

Dr. Niti Bhasin, Assistant Professor, Department of Commerce, Delhi School of Economics, University of Delhi. 
Foreign investment plays an important role in the long-term economic development of a country by augmenting availability of capital, enhancing competitiveness of the domestic economy through transfer of technology, strengthening infrastructure, raising productivity, generating new employment opportunities and boosting exports. Foreign investment, therefore, is a strategic instrument of development policy.

In view of the importance of FDI as an important policy goal, many countries of the world are now actively competing with each other to attract FDI which, in many cases, is done by offering tax incentives. Conventionally, tax incentives have been considered ineffective to promote or direct economic activity. A major portion of the studies undertaken prior to 1990 concluded that taxation was a relatively minor consideration in most FDI decisions. More recent studies, however, suggest otherwise, i.e., tax considerations have become an increasingly important factor in investment decisions and that special tax incentives have become substantially more effective as instruments for attracting FDI than they were 10 or 20 years ago. Clark (2000, p.1176) observed, "Empirical work using improved data measuring FDI offers convincing evidence that host country taxation does indeed affect investment flows. Moreover, recent work finds host country taxation to be an increasingly important factor in location decisions." Tax incentives for FDI have been around for a long time but such incentives have increased substantially in range and in scope since the 1990s and strong competition to attract foreign direct investment has developed in many parts of the world. Another aspect that merits attention is the role of expenditure policy of the government in attracting FDI. The expenditure of government on production of public inputs such as infrastructure and better education facilities can be of productive use to both foreign and domestic investors and can also play a significant role in attracting foreign investors.

\subsection{Rationale of the study}

Globalization and the resulting increase in capital mobility have created opportunities for tax competition among countries eager to attract FDI. In the process, tax incentives have assumed new and increasing importance. Use of incentives to attract foreign investment is usually justified by the expected 


\section{6 | VISION: Journal of Indian Taxation}

additional beneficial effects of the foreign investment on the host economy. It needs to be noted, however, that while tax incentives may lead to incremental foreign investment, such incentives may also lead to weakening of public finances through decreased tax revenues. As would be evident from the review of literature, numerous studies have focused on the effects of taxation on both inbound and outbound foreign direct investment.

While the role of taxation (first dimension of fiscal policy) in influencing FDI has received considerable attention in literature lately, there has been very less work on examining the role of fiscal policy as a whole on FDI inflows. The second dimension of fiscal policy that relates to the expenditure of the government has not received much attention in terms of its impact of FDI. While tax incentives (revenue side of the fiscal policy) may be used as instruments to attract FDI, the expenditure of government on production of public inputs (expenditure side of fiscal policy) which may be of productive use to both foreign and domestic investors can also play a significant role in attracting foreign investors. While countries competing for FDI may want to offer a better tax environment, governments can also tend to make efforts to modernize the infrastructure, increase local productivity-enhancing human capital formation, and improve the overall business environment of the country. This, in turn, can be achieved if the expenditure policy of the government is welfare-oriented. Such policies can be a powerful means of attracting FDI and also of promoting economic development, because such measures result in benefits for domestic producers as well. Thus, government expenditure on public inputs such as the infrastructure, better public educational institutions or a more efficient judiciary can help in attracting FDI while also benefitting domestic producers.

In view of the abovementioned potential gains from a well-conceived fiscal policy, it becomes necessary to gauge the impact of the fiscal policy of a country in attracting FDI. There is very sparse literature examining the impact of overall fiscal policy of the government on FDI, particularly with respect to India or the Asian region. This study would attempt to bridge the gap in literature by examining the impact of both the revenue and expenditure side of fiscal policy on FDI inflows in select economies of the Asian region. The economies selected would be the top ten recipient economies of FDI inflows in the Asian region. 


\subsection{Review of literature}

In recent years, a large body of research has focused on the effects of taxation on both inbound and outbound foreign direct investment. A major part of the literature has related capital flows to some measure of an effective tax rate on capital income. The empirical results relating to inward FDI have been mixed.

The earlier literature on the subject attempted to determine if tax policy was one of the key factors in the decision-making process of multinational companies. It examined the impact of tax policy on FDI from a global perspective using investors' surveys and time-series econometric analysis.

Snoy (1975) pioneered a statistical investigation of investment flows over the years 1966-69 from several leading source countries to a number of hostcountry destinations. His explanatory variables included source-host tax differentials bearing on retained earnings or remitted dividends of foreign subsidiaries, as well as other controls such as national growth-rate differentials. The tax variables are not very robust in their statistical significance, but their coefficients always take the predicted signs, and their magnitudes imply that tax changes would have large effects. Root and Ahmed (1978) performed an econometric study with data for 41 developing countries for the period 19661970. They classified countries into three categories of unattractive, moderately attractive, and highly attractive according to their average annual per capita inflow of FDI. Forty-four variables were chosen as potentially significant discriminators of the three country groups. Among the six policy-related discriminators were three relating to tax levels. Of these, corporate tax rates proved to be an effective discriminator of the three defined country groups; however, tax incentive laws and liberality were not found to be effective discriminators.

A significant body of research by economists has emphasized the effects of taxation on FDI into the US. This literature has generally examined reducedform relationships between capital flows and measures of after-tax rates of return or effective tax rates on capital income. Hartman (1985) examined the implications of the 'residence' approach to taxing foreign source income as is employed by the United States. He argued that because the repatriation of earnings to the home country investor and not the earnings themselves are 
typically the source of tax liability, the foreign source income tax should affect foreign investment differently depending on the required transfer of funds within the firm. Hartman, in his work, brought out that the additional taxes paid upon repatriation may have no effect on investment financed by retained earnings. Hartman (1984) performed an empirical analysis relating to the influence of domestic tax policy on FDI in the United States using annual time series data for the fifteen-year period 1965-1979. He estimated the effects on U.S. inbound FDI, of changes in the after-tax rates of return received by foreign investors in U.S. inbound FDI and by investors in U.S. capital generally. He also included, as an explanatory variable, the tax rate on U.S. capital owned by foreign investors relative to that owned by U.S. investors. Using the log of the ratio of FDI to U.S. GNP as the dependent variable, Hartman's results indicate that the FDI-GNP ratio increases as the after-tax rates of return rise and decreases as the relative tax rate on foreigners rises.

Hartman's study provoked many subsequent rounds of replication and refinement. Boskin and Gale (1987) re-estimated Hartman's model using data over the period 1956-84. They studied aggregate U.S. inflows and outflows of foreign direct investment and found that a domestic tax policy change that increases domestic investment by $\$ 1$ will prompt $\$ 0.08$ to 0.27 of additional investment from abroad and deter $\$ 0.04$ of U.S. investment abroad. While their results vary across specifications and time periods, they are qualitatively consistent with Hartman's original findings. Beginning with Hartman's work, much of the empirical literature on FDI into the United States has focused on the distinction between retained earnings and transfers (Young, 1988; Slemrod, 1990; Shah and Slemrod, 1991; Scholes and Wolfson, 1991)

Auerbach and Hassett (1993) present a model of FDI that takes into account the different tax treatments of acquisition of old and new capital in order to isolate more precisely the effects of taxation on FDI into the United States. Their results cast doubt on the position that increases in FDI in the US is due to the changes in tax incentives. Many economists have used the q-theory approach to examine the sensitivity of taxes to investment. Summers (1981) presented an analysis of the effects of tax policy on capital accumulation and valuation based on James Tobin's $q$ theory of investment. The $q$ theory of investment is derived by assuming that firms face adjustment costs and make investment and output 
decisions with the objective of maximizing market value. Summers constructed a tax-adjusted $q$ (referred to as Q), by taking into account debt finance, personal taxes, and depreciation. He then examines the determinants of non-financial corporate investment over the period 1931-78 using annual data. Investment equations using "tax-adjusted $q$ " as an explanatory variable are shown to have somewhat more explanatory power than equations that rely on the $q$ variable that is customarily used, implying thereby the importance of tax effects. Home and host country tax parameters have been incorporated in theoretical definitions of the subsidiary's marginal q by Alworth (1988), and Altshuler and Fulghieri (1994), under different assumptions about the taxing regime and dividend policy. Cummins and Hubbard (1995) also used a model of investment based on taxadjusted $q$ to examine the effects of taxation on foreign direct investment. They employed panel data on outbound foreign direct investment by subsidiaries of U.S. multinational firms. (Panel data is used to focus on "new investment" which is not possible with aggregate data). Their empirical results support the notion that taxes matter for U.S. firms' investment decisions.

Devereux and Freeman (1995) hold that taxation does affect the location of FDI. They estimate the impact of taxation on FDI flows using data on flows between seven countries for 1984 through 1989, and a sophisticated measure of the cost of capital. Similarly, a study relating to FDI in Japan, conducted by Weinstein (1996), concludes that the government tax and financial policy affects foreign takeovers in the country. Gropp and Kostial (2001) have found a strong link between FDI and the tax regime of a country by comparing a group of countries with the lowest tax rates to a group of countries with the highest tax rates. They observed that during the sample period (1988-97), countries in the low-tax group experienced much lower net FDI outflows relative to the high-tax group; net outflows in the low-tax group were about half those in the high tax group. Sury (2003) examines the possible effects of domestic taxes and rates of return on FDI in India. Using the econometric models given by Hartman (1984) and Young (1988) for a sixteen-year sample period, i.e., 1985-2000, the effects of taxes on FDI in India are found to be quite strong. In general, the results show that an increase in the specific after-tax rate of return realised by foreign investors in India leads to an increase in foreign investment. Further, it has been found that an increase in the overall after-tax rate of return on capital in India 
80 | VISION: Journal of Indian Taxation

leads to a fall in FDI. The results also indicate that a decline in the tax rate faced by an Indian investor relative to the tax rate faced by a foreign investor tends to cause a significant decrease in the level of foreign investment. Conversely, a change in India's tax policy which tends to diminish the tax rate faced by foreigners (e.g., a decrease in corporate income tax on foreign companies) provides strong encouragement to increase FDI in India. Therefore, FDI is elastic with respect to the relative net-of-tax return. Thus, the empirical analysis suggests that FDI in India is strongly affected, in the manner predicted on the basis of the models used, by changes in domestic tax policy.

Yinusa (2013) looks at the impact of fiscal incentives for FDI and infrastructure development on manufacturing Foreign Direct Investment in thirteen Southern African Development Community (SADC) countries for the period 1995 to 2007 . The findings show that while fiscal incentives alone are not significant determinants of manufacturing FDI to these countries; however, fiscal incentives interacting with infrastructure are positively significant in explaining manufacturing FDI. The paper thus concludes that in seeking to attract manufacturing FDI to this group of countries, priority should be given to things like infrastructure development and exchange rate policy design rather than fiscal incentives that are only complementary.

\subsection{Objectives of the Study}

The main objectives of the study are:

1. To analyse the fiscal policy environment of India and Asian countries under study.

2. To identify the major determinants of FDI inflows in the Asian region with special emphasis on fiscal policy variables.

3. To give policy recommendations in the light of conclusions that will obtained.

\subsection{Tax Environment: A Comparison of Select Asian Economies}

Investment prospects for developing Asia as a whole are bright, given the quality of the underlying economic determinants of foreign direct investment, the 
recovery of the region from the financial crisis, and the ongoing liberalisation and restructuring efforts that are now widespread.

\subsection{Tax Year}

The tax year (assessment year) in China, Singapore, Malaysia and Thailand, is the calendar year running from January 1 to December 31. The tax year in Hong Kong, Korea and India is the financial year commencing on April 1 every year. In Philippines, a corporation may use the calendar year or a fiscal year as its tax year.

\subsection{Scope of Taxable Income}

In China, domestic enterprises are taxed on their worldwide income. All foreign investment enterprises (FIEs) including joint ventures, co-operative or contractual joint ventures and entities wholly owned by foreigners are subject to tax on their worldwide income. However, a foreign tax credit is allowed for income taxes paid to other countries by branches of an FIE, limited to the income tax payable on the same income in China. Foreign enterprises, defined to include foreign companies, enterprises and other economic organisations, are subject to tax only on their income from sources in China.

The basis of taxation in Hong Kong is territorial. Companies carrying on business in Hong Kong are subject to profits tax on profits arising in or derived from Hong Kong. However, a company not carrying on business in Hong Kong is not subject to profits tax, even on income from sources in Hong Kong. A Hong Kong business is not subject to profits tax on income sourced outside Hong Kong. Thus, the basis of taxation in Hong Kong is territorial.

Korean domestic corporations are taxed on their world-wide income, including income earned by foreign branches. A domestic corporation is one that has its head office in Korea. Foreign corporations are taxed on Korean-source income only.

In Singapore, corporate tax is charged on worldwide income, i.e. income derived from sources in Singapore together with income from sources outside Singapore, if received in Singapore. A non-resident company carrying on business in Singapore is similarly taxed on Singapore-source income and on foreign-source income received in Singapore if that income is effectively 
connected with a Singapore permanent establishment. However, a non-resident company that is not operating in or from Singapore is generally not taxed on foreign-source income received in Singapore. A company is resident in Singapore if management and control of its business are exercised in Singapore; the place of incorporation is not relevant.

Resident companies in Thailand are subject to corporate income tax on their worldwide income. Thai resident companies are those incorporated in Thailand. Branches of foreign corporations are subject to Thai tax on Thailand-source income only.

Resident and non-resident companies in Malaysia are taxed on income accruing in or derived from Malaysia, i.e. on a territorial basis. Resident companies engaged in banking, insurance, shipping or air transport are taxable on their world-wide income. A company is resident in Malaysia if its control and management is exercised in Malaysia; the place of incorporation is irrelevant.

Domestic corporations in Philippines are taxed on their worldwide net taxable income. Domestic corporations are corporations incorporated under the laws of Philippines. Resident foreign corporations are taxed on their net taxable income, and non-resident foreign corporations are taxed on gross income derived from the Philippines. A resident foreign corporation is one created under foreign laws and engaged in trade or business in the Philippines. Any other foreign corporation is considered a non-resident.

An Indian resident corporation is subject to tax on its worldwide income, while non-resident companies are taxable on incomes that arise out of their Indian operations, or in certain cases, income that is deemed to arise in India. An Indian company is always resident in India. A foreign company is resident in India only if the control and management of its affairs is situated wholly in India.

\subsection{Rates of Corporate Income Tax}

In China for the year 2012, domestic state-owned enterprises would be subject to tax at the rate of 25 percent. In general, FIEs (Foreign Investment Enterprises) and foreign enterprises with establishments in China are taxed at an effective rate of 25 percent. A reduced rate of 15 percent applies to FIEs and foreign enterprises with establishments in China, located in Special Economic Zones (SEZs). Further, many foreign investors have been given tax waivers or 
reduced tax rates as an incentive to invest in China. China introduced two different corporate income tax systems respectively for domestic and overseas firms since its 1994 tax reform with overseas firms enjoying lower tax burden. Preferential tax offers given to overseas firms helped China attract overseas investment, technology and expertise The actual average income tax rate has remained at 14 percent for foreign companies since China formulated the preferential policy for overseas-funded enterprises in mid-1980s in a bid to lure foreign investment.

The rate of corporate profits tax in Hong Kong for 2012 is 16.5 percent for all companies carrying on business in Hong Kong. In Korea, for domestic corporations, the rate of corporate tax is 22 percent. A resident surtax equal to 10 percent of corporate tax is also imposed. For foreign corporations with a domestic business operation, the same tax rates as those for domestic corporations apply. As for the year 2012, the standard corporate income tax rate in Singapore is 17 percent for both domestic and foreign companies.

In Thailand, from January 1, 2012, resident companies and branches of foreign corporations are subject to corporate income tax at a flat rate of 23 percent on taxable profits. The rate of corporate tax in Malaysia is 25 percent, applicable to both resident and non-resident companies. Domestic and foreign corporations in Philippines are subject to tax at a rate of 30 percent.

For the income year 2012-13, domestic corporations in India are subject to tax at a rate of 30 percent while foreign companies are taxed at the rate of 40 percent.

\subsection{Capital Gains and Losses}

In China, Thailand and Korea, capital gains and losses are treated in the same way as other taxable income and are thus subject to tax at the normal corporate income tax rate. In Hong Kong, capital gains are not taxed, and capital losses are not deductible for profits tax purposes. Capital gains are not taxed in Singapore.

Malaysia does not tax income from capital gains except gains derived from the disposal of real property or shares in a real property company. In the latter case, the applicable rates range from 5 percent to 30 percent depending on the number of years for which the assets are held.

In Philippines, a 6 percent tax is imposed on capital gains presumed to have 


\section{4 | VISION: Journal of Indian Taxation}

been derived from the sale, exchange or disposition of land or buildings classified as capital assets. Different rates of tax apply to capital gains from sale of shares, depending on the amount of gains and listing of shares on stock exchange.

In India, long-term capital gains are taxed at 20 percent. Capital gains on short-term capital assets are taxed at the normal corporate income tax rates.

\subsection{Dividends}

Profits of FIEs and foreign enterprises in China, either in the nature of dividends or branch profits are not subject to any withholding tax when remitted outside China. In Hong Kong, dividends are exempt from tax in the hands of the recipient. There is neither a withholding tax nor a credit system for dividends in Hong Kong; all dividends are paid gross as declared and no taxes are paid on declaration. In Korea, a corporation must include dividends received in taxable income. However, dividends received by a domestic corporation from a domestic subsidiary may be deducted from the taxable income according to a formula specified in the law.

In Singapore, effective from January 1, 2003, a one-tier system of taxation replaced the earlier full imputation system. Under the one-tier system, dividends paid by a company are exempt from income tax in the hands of shareholders, regardless of whether the dividends are paid out of taxed income or tax-free gains.

In Thailand, one-half of dividends received by resident companies from other resident companies may be excluded from taxable income. However, the full amount may be excluded if certain conditions are satisfied. A foreign company receiving dividends from or in Thailand is liable to a withholding tax rate of 10 percent.

In Malaysia, a resident company paying dividends must deduct income tax at the rate of 28 percent. A non-resident company may distribute the after-tax profits without incurring any additional tax liability.

In Philippines, dividends received by a domestic or resident foreign corporation from a domestic corporation are not subject to tax. If the recipient is a non-resident foreign corporation, the tax imposed is 32 percent. This tax may be reduced to 15 percent if the country of domicile of the recipient does not impose any tax on income derived from outside such country or if it allows a 
credit for taxes deemed paid in the Philippines equivalent to 17 percent. This credit represents the difference between the regular corporate income tax rate and the 15 percent preferential tax on dividends. The 15 percent tax also applies if the dividend is not taxed in the recipient's country of domicile.

In India, dividends paid by resident companies are exempt from tax in the hands of the recipients. However, resident companies must pay a dividend distribution tax (DDT) at a rate of 13.068 percent (including the 2.5 percent surcharge and the 2 percent education cess) on dividends declared, distributed or paid by them. The DDT paid is a non-deductible expense.

\subsection{Foreign Tax Relief}

In China, a tax credit is allowed for foreign taxes paid by FIEs in other countries, not exceeding the relevant tax payable on such income in China. Excess foreign tax credits may be carried forward for a period of 5 years. Hong Kong allows deduction for foreign taxes paid only in certain circumstances. A foreign tax credit is available only under the tax arrangement between Hong Kong and China. Korea allows a tax credit for corporate tax paid to a foreign government. The relief cannot exceed the lesser of the tax paid abroad and the Korean tax amount equivalent to the ratio of the income from foreign sources to the total taxable income. Any excess of foreign tax paid over the limitation may be carried forward to the following 5 years.

Foreign tax relief in Singapore is limited to the lower of the foreign tax paid and the tax payable on that income in Singapore. Apart from foreign tax relief under double tax treaties (with 52 countries), a unilateral tax credit system is also available for certain income remitted to Singapore that is derived from countries that have not entered into tax treaties with Singapore. In addition, unilateral relief is granted for underlying foreign taxes paid by a 25 percent owned foreign subsidiary on profits out of which the dividends are paid.

Like Singapore, Thailand has concluded double tax treaties with 46 countries. In general, under the treaties, foreign tax relief is limited to the lower of the foreign tax and the amount of Thai tax calculated on such income. Foreign tax payable in non-treaty countries may be credited against Thai tax, limited to the Thai tax computed on the foreign income.

As Malaysia generally does not tax foreign-source income, no foreign tax 


\section{6 | VISION: Journal of Indian Taxation}

relief is provided to companies, except to companies engaged in banking, insurance, shipping or air transport. These companies are taxed on their worldwide income and may claim foreign tax relief with respect to foreign taxes imposed on their foreign-source income.

In Philippines, tax credits are allowed to domestic corporations for income taxes paid or accrued to any foreign country, subject to certain limitations. Alternatively, such income taxes may be claimed as a deduction from taxable income. Resident foreign corporations are not allowed to credit tax paid to foreign countries against Philippine-source income.

In India, foreign tax relief for the avoidance of double taxation is governed by tax treaties with several countries. If no such agreements exist, resident corporations may claim a foreign tax credit for the foreign tax paid. The amount of the credit is the lower of the Indian tax payable on the income (that is taxed twice) and the foreign tax paid.

\subsection{Determinants of FDI Inflows in Asia}

The study examines the determinants of FDI inflows of select countries from Asia with special emphasis on the role of host country fiscal policy in FDI decisions. For this, panel data has been employed for seven countries that are amongst the top recipient economies of FDI inflows in the Asian region for the period 1991-2011. (Two countries Hong Kong and Vietnam have been excluded due to unavailability of data on fiscal policy). A fixed effects (Least Squares Dummy Variables (LSDV)) model has been developed that captures the important 'pull' factors that make an economy an attractive destination for FDI. Apart from the usual macro-economic factors and policy factors such as trade openness and FDI openness, we try to find out if an attractive fiscal policy boosts FDI flows to an economy. Further, a double-log model will be used in the analysis.

\subsection{Sample period}

As mentioned above, the period selected for the study is 1991-2011. Due to lack of data availability for many countries for years prior to 1991, the above period has been selected. The countries included will be China, Singapore, India, 
Indonesia Thailand, Republic of Korea, Philippines, and Malaysia. These countries are amongst the top recipient economies in the South, East and SouthEast Asian region.

\subsection{Data Sources}

The data on FDI inflows has been collected from UNCTAD online statisticswww.unctad.org/fdistatistics. The independent variables used in the study would include GDP, GDP per capita, trade openness, FDI openness, real interest rate, total labour force and air transport (which is taken as a proxy for infrastructure). To study the effect of fiscal policy, the variables included are number of bilateral tax treaties and developmental expenditure of the government as percentage of total government expenditure. With respect to these independent variables, data on real GDP, real GDP per capita, exports and imports, real interest rate, air transport and total labour force has been obtained from various issues of World Development Indicators report of the World Bank. FDI stock data required to calculate the index of FDI openness can be obtained from UNCTAD online statistics- www.unctad.org/fdistatistics. The explanatory variables describing the fiscal policy of the government would include the corporate tax rates for foreign companies and the developmental expenditure of the government as percentage of total government expenditure. Data on number of bilateral tax treaties has been collected from UNCTAD online statistics, while for details of government expenditure, data has been obtained from various issues of the Government Finance Statistics Yearbook, International Monetary Fund.

\subsection{Research methodology}

With the help of panel data for ten countries over a twenty one year period from 1991-2011, the study models the role of fiscal policy in promoting FDI. A fixed effects (Least Squares Dummy Variables (LSDV)) model will be developed that will capture macro-economic factors, policy factors such as openness and fiscal policy factors. To augment the model's analytical richness, the study would also use the Principal Component Analysis

\section{Modelling Determinants of FDI as variables}

The general form of the FDI model used in this study is:

FDI inflows $=\mathrm{f}$ (GDP, GDP per capita, Trade Openness, FDI Openness, Labour 
availability, Infrastructure, Interest Rate, Tax treaties, Developmental expenditure of the government)

GDP of the host country is indicative of its market size and this is a major explanatory variable, particularly in the case of market-seeking FDI. A higher GDP implies a large market size which would help a firm to reap economies of scale through specialization. The proxy used for market demand is real GDP per capita which is an indicator of the buying capacity of the consumers. When GDP per capita in the host country is high, there will be sufficient demand to justify economies of scale; hence the firm may contemplate investing in this country to optimize production.

The other policy variables are FDI openness and trade openness of the host country. FDI openness of the host country will be obtained by dividing the value of FDI stock by the country's GDP. FDI openness of an economy is expected to have a positive and encouraging impact on FDI inflows into the economy. Trade openness will be obtained by dividing the total trade flows of a country by its GDP. The impact of trade openness on FDI inflows can work in either direction. If exports and FDI inflows exhibit a complementary relationship, then trade openness would lead to increased trade as well as FDI inflows. If however, the relationship is one of substitution, then trade openness would encourage exports as an alternative to FDI and hence lead to a fall in FDI.

Labour abundance is believed to be an important factor attracting FDI into developing countries. To capture this, the total labour availability in the selected countries has been taken. Further, infrastructure has been included as countries with better infrastructure would facilitate setting up and operation of business. Air transport (registered carrier departures worldwide) has been taken as a proxy for infrastructure.

As a main objective of the study is to examine the role of fiscal policy, I have included additional explanatory variables namely the number of bilateral tax treaties entered into by a country and developmental expenditure of the government as a percentage of its total expenditure. A greater propensity to sign tax treaties is expected to contribute to an environment of fiscal certainty and hence increase FDI inflows. The proportion of developmental expenditure of the government would include the expenditure on economic affairs (mining, agriculture etc.), housing and community amenities, health and education. All 
these expenditures are taken as a proportion of total outlay of the government. These expenditures of the Government lead to the creation of physical or financial assets and enhance human capital. Therefore, they are expected to increase FDI inflows.

\section{Panel Regression Models}

A common panel data regression model looks like $y_{i t}=a+b x_{i t}+\varepsilon_{i t}$

where, $y$ is the dependent variable, $x$ is the independent variable, $a$ and $b$ are coefficients, $i$ and $t$ are indices for individuals and time. The error $\epsilon_{i t}$ is very important in this analysis. Assumptions about the error term determine whether we speak of fixed effects or random effects. In a fixed effects model, $\epsilon_{i t}$ is assumed to vary non-stochastically over $i$ or $t$ making the fixed effects model analogous to a dummy variable model in one dimension. In a random effects model, $\epsilon_{i t}$ is assumed to vary stochastically over $i$ or $t$ requiring special treatment of the error variance matrix.

The Fixed Effects Model (Least Squares Dummy Variable Model): The models which capture the individual effects are called fixed effects models. Random effects models, on the other hand capture the generalized effects. This study uses fixed effects panel model that would have constant slopes of the independent variables but intercepts would differ according to the cross-sectional (group) unit - in our case, the country. In such cases although there are no significant temporal effects, there are significant differences among countries in this type of model, which is what we would normally expect if we were to analyse FDI flows in general. To formulate this model, country dummies have been included. For any qualitative regressor, the number of dummy variables introduced must be one less than the categories of that variable; hence, we introduce 6 (n-1) dummies. For a particular partner country, the dummy variable takes the value of ' 0 ' for the year when treaty is not present and ' 1 ' for the year when treaty is present. The base country for which no dummy variable is assigned is China.

\section{Principal Component Analysis}

When we consider developmental variables like population, GDP, and so on, there is bound to be a high degree of correlation amongst independent variables. To deal with this econometric problem, we would use the Principal Component 


\section{0 | VISION: Journal of Indian Taxation}

Analysis (PCA) to determine the "principal variables." The PCA methodology tells us the total variance explained by each retained principal component as well as the cumulative percentage of the explained variation. This is a measure of the explanatory power of the component for the information content of the procedure. There are various methods of rotation but the most popular method is the Varimax with the Kaiser normalization. The purpose of the rotation is to make the interpretation of the PCA more meaningful. Method of rotation however retains the same information and explanatory power.

\section{Model specification}

The estimating equation is:

$$
\begin{aligned}
\mathrm{Y}_{\mathrm{it}}=\alpha+\beta_{1} \mathrm{D} 2+\beta_{2} \mathrm{D} 3+\beta_{3} \mathrm{D} 4+\beta_{4} \mathrm{D} 5+\beta_{5} \mathrm{D} 6+\beta_{6} \mathrm{D} 7+\beta_{7}(\mathrm{RGDP})+\beta_{8} \\
(\mathrm{RGDPCAP})+\beta_{9}(\mathrm{TOPEN})+\beta_{10}(\mathrm{FOPEN})+\beta_{11}(\mathrm{BTTS})+ \\
\beta_{12}(\mathrm{PRODEVEXP})+\beta_{13}(\mathrm{TOTLAB})+\beta_{14}(\text { AIRTRANS })+\mathrm{u}_{\mathrm{it}}
\end{aligned}
$$

where;

Yit - FDI inflows

RGDP - real GDP of host country

RGDPCAP - real GDP per capita of host country

TOPEN - trade openness of host country

FOPEN - FDI openness of the host country

BTTS - number of bilateral tax treaties entered into by host country in time period $\mathrm{t}$

PRODEVEXP - proportion of developmental expenditure of the government as part of total expenditure

TOTLAB - total labour force in the host economy

AIRTRANS - air transport (registered carrier departures worldwide)

\subsection{Results and Analysis}

The initial regression results are presented in Table1. For a large number of explanatory variables, we get insignificant coefficients while the $\mathrm{R}^{2}$ is quite high. This is indicative of multicollinearity. It implies that some explanatory variables are correlated. To avoid this problem, we use the Principal Component Analysis (PCA). 
The Impact of Fiscal Policy on Foreign Direct Investment Inflows $\mid 91$

Table 1: Initial Regression Results

\begin{tabular}{|c|c|c|c|c|}
\hline \multicolumn{5}{|c|}{ Dependent Variable: FDI } \\
\hline \multicolumn{5}{|c|}{ Method: Panel Least Squares } \\
\hline \multicolumn{5}{|c|}{ Sample: 19912011} \\
\hline \multicolumn{5}{|l|}{ Periods included: 21} \\
\hline \multicolumn{5}{|c|}{ Cross-sections included: 7} \\
\hline \multicolumn{5}{|c|}{ Total panel (balanced) observations: 147} \\
\hline Variable & Coefficient & Std. Error & t-Statistic & Prob. \\
\hline $\mathrm{C}$ & -46129.97 & 22503.23 & -2.049926 & 0.0424 \\
\hline RGDP & $-5.53 \mathrm{E}-09$ & $1.21 \mathrm{E}-08$ & -0.457242 & 0.6482 \\
\hline RGDPCAP & 0.296391 & 0.763324 & 0.388289 & 0.6984 \\
\hline TOPEN & -40.98992 & 45.71990 & -0.896544 & 0.3716 \\
\hline FOPEN & 257.2737 & 51.35681 & 5.009534 & 0.0000 \\
\hline BTTS & 334.9947 & 302.1247 & 1.108796 & 0.2695 \\
\hline PRODEVEXP & -87.63163 & 92.11806 & -0.951297 & 0.3432 \\
\hline TOTLAB & $9.71 \mathrm{E}-05$ & $3.58 \mathrm{E}-05$ & 2.714168 & 0.0075 \\
\hline AIRTRANS & 0.043648 & 0.014166 & 3.081142 & 0.0025 \\
\hline D2 & 52432.43 & 24546.26 & 2.136066 & 0.0345 \\
\hline D3 & 8304.446 & 9133.133 & 0.909266 & 0.3649 \\
\hline D4 & 51932.93 & 23361.73 & 2.222992 & 0.0279 \\
\hline D5 & 38214.51 & 21847.69 & 1.749133 & 0.0826 \\
\hline D6 & 47868.05 & 22938.41 & 2.086808 & 0.0388 \\
\hline D7 & 48770.39 & 25344.35 & 1.924310 & 0.0565 \\
\hline R-squared & 0.945639 & \multicolumn{2}{|c|}{ Mean dependent var } & 14358.39 \\
\hline Adjusted R-squared & 0.939873 & \multicolumn{2}{|c|}{ S.D. dependent var } & 23661.61 \\
\hline S.E. of regression & 5801.997 & \multicolumn{2}{|c|}{ Akaike info criterion } & 20.26624 \\
\hline Sum squared resid & $4.44 \mathrm{E}+09$ & \multicolumn{2}{|c|}{ Schwarz criterion } & 20.57139 \\
\hline Log likelihood & -1474.569 & \multicolumn{2}{|c|}{ Hannan-Quinn criter. } & 20.39023 \\
\hline F-statistic & 164.0150 & \multicolumn{2}{|c|}{ Durbin-Watson stat } & 1.362740 \\
\hline Prob(F-statistic) & 0.000000 & & & \\
\hline
\end{tabular}




\section{2 | VISION: Journal of Indian Taxation}

To apply the PCA, we first conduct the KMO and Bartlett's test of sphericity. The results of the test are given in Table 2. As the KMO measure is greater than 0.53 and Bartlett's test has a significant coefficient, hence the PCA method can be applied.

Table 2: KMO and Bartlett's Test

\begin{tabular}{|l|l|r|}
\hline \multicolumn{2}{|l|}{ Kaiser-Meyer-Olkin Measure of Sampling Adequacy. } & .530 \\
\hline Bartlett's Test of Sphericity & Approx. Chi-Square & 1424.889 \\
\cline { 2 - 3 } & Df & 28 \\
\cline { 2 - 3 } & Sig. & .000 \\
\hline
\end{tabular}

From the PCA methodology, four components have been extracted as shown in Table 3. The cumulative explained variance of the four components is about 94\%. The rotated component scores obtained are given in Table 4.

Table 3: Total Variance Explained

\begin{tabular}{|c|c|c|c|c|c|c|c|c|c|}
\hline \multirow[b]{2}{*}{ 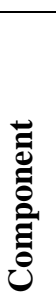 } & \multicolumn{3}{|c|}{ Initial Eigenvalues } & \multicolumn{3}{|c|}{$\begin{array}{l}\text { Extraction Sums of } \\
\text { Squared Loadings }\end{array}$} & \multicolumn{3}{|c|}{$\begin{array}{c}\text { Rotation Sums of Squared } \\
\text { Loadings }\end{array}$} \\
\hline & $\stackrel{\vec{\pi}}{0}$ & 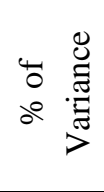 & 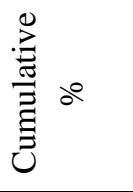 & 胥 & 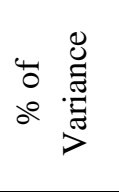 & $\frac{\stackrel{\Xi}{\Xi}}{\stackrel{\Xi}{\Xi}} \circ^{\circ}$ & $\stackrel{\sqrt[\pi]{0}}{0}$ & 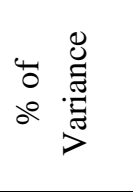 & $\frac{\stackrel{D}{\Xi}}{\stackrel{\Xi}{\Xi}} \delta^{\Xi}$ \\
\hline 1 & 4.02 & 50.36 & 50.36 & 4.02 & 50.36 & 50.36 & 2.71 & 33.91 & 33.91 \\
\hline 2 & 1.97 & 24.67 & 75.04 & 1.97 & 24.67 & 75.04 & 2.46 & 30.82 & 64.73 \\
\hline 3 & .966 & 12.07 & 87.11 & 0.96 & 12.07 & 87.11 & 1.34 & 16.78 & 81.51 \\
\hline 4 & .570 & 7.126 & 94.24 & 0.57 & 7.12 & 94.24 & 1.01 & 12.72 & 94.24 \\
\hline 5 & .242 & 3.024 & 97.267 & & & & & & \\
\hline 6 & .138 & 1.730 & 98.997 & & & & & & \\
\hline 7 & .076 & .953 & 99.949 & & & & & & \\
\hline 8 & .004 & .051 & $\begin{array}{r}100.00 \\
0\end{array}$ & & & & & & \\
\hline
\end{tabular}

From Table 4, we extract the principal variables for each of the components. Consequently, the four principal variables are FOPEN (0.957), AIRTRANS (0.976), PRODEVEXP (0.907) and BTTs (0.987). The regression result of the 
principal variables is shown in Table 5. The coefficients of FDI openness and air transport are highly significant and have expected signs. This implies that the openness of an economy towards capital movement contributes to greater and smoother flow of FDI. FDI openness of the developing economies under study have, thus, contributed to increased FDI inflows. Further, infrastructure has also played an important role. As the sign is positive, it implies that countries with well-developed and competitive infrastructure make for attractive FDI destinations. Infrastructure plays a key role in facilitating business operations. The coefficients of fiscal policy variables, namely bilateral tax treaties and developmental expenditure, however, are insignificant. This implies that fiscal policy variables have still not become prime considerations in FDI decisionmaking process. A well-conceived fiscal policy may act as a facilitator in that it can make doing business easier. For instance, bilateral tax treaties create an environment of fiscal and legal certainty. However, these factors are not the considerations on which the decision regarding location of production would be based. As far as the country dummies are concerned, we get significant coefficients for all country dummies thereby implying that there are significant differences amongst countries under study.

Table 4: Rotated Component Matrix ${ }^{a}$

\begin{tabular}{|l|c|c|c|c|}
\hline \multirow{2}{*}{} & \multicolumn{5}{|c|}{ Component } \\
\cline { 2 - 5 } & 1 & 2 & 3 & 4 \\
\hline RGDP & -.113 & .949 & -.259 & .012 \\
\hline RGDPCAP & .918 & -.110 & .084 & .135 \\
\hline FOPEN & .957 & -.065 & .039 & .038 \\
\hline TOPEN & .908 & -.167 & .257 & .055 \\
\hline BTTs & .128 & .003 & .079 & .987 \\
\hline ProDevexp & .165 & -.333 & .907 & .071 \\
\hline Totlab & -.254 & .677 & -.592 & -.124 \\
\hline Airtrans & -.090 & .976 & -.147 & .020 \\
\hline $\begin{array}{l}\text { Extraction Method: Principal Component Analysis. } \\
\text { Rotation Method: } \text { Varimax with Kaiser Normalization. }\end{array}$ \\
\hline a. Rotation converged in 5 iterations. \\
\hline
\end{tabular}


94 | VISION: Journal of Indian Taxation

Table 5: Regression Results of Principal Variables

Dependent Variable: FDI

Method: Panel Least Squares

Sample: 19912011

Periods included: 21

Cross-sections included: 7

Total panel (balanced) observations: 147

\begin{tabular}{crrrr}
\hline \hline Variable & Coefficient & Std. Error & t-Statistic & Prob. \\
\hline \hline C & 14740.30 & 3078.879 & 4.787555 & 0.0000 \\
FOPEN & 229.2860 & 24.45642 & 9.375286 & 0.0000 \\
AIRTRANS & 0.043616 & 0.001845 & 23.64049 & 0.0000 \\
PRODEVEXP & -69.81249 & 86.46601 & -0.807398 & 0.4208 \\
BTTS & 126.7462 & 295.3830 & 0.429091 & 0.6685 \\
D2 & -15048.46 & 3617.733 & -4.159638 & 0.0001 \\
D3 & -15859.95 & 2326.701 & -6.816499 & 0.0000 \\
D4 & -10921.45 & 3807.287 & -2.868565 & 0.0048 \\
D5 & -23143.78 & 2957.842 & -7.824550 & 0.0000 \\
D6 & -14351.28 & 2731.021 & -5.254914 & 0.0000 \\
D7 & -18633.42 & 3550.302 & -5.248403 & 0.0000 \\
\hline \hline R-squared & 0.942239 & Mean dependent var & 14358.39 \\
Adjusted R-squared & 0.937991 & S.D. dependent var & 23661.61 \\
S.E. of regression & 5892.104 & Akaike info criterion & 20.27250 \\
Sum squared resid & $4.72 E+09$ & Schwarz criterion & 20.49627 \\
Log likelihood & -1479.028 & Hannan-Quinn criter. & 20.36342 \\
F-statistic & 221.8510 & Durbin-Watson stat & 1.306461 \\
Prob(F-statistic) & 0.000000 & & \\
\hline \hline
\end{tabular}

\subsection{Conclusion}

Developing countries of the world are competing with each other to attract FDI. In the light of this, it is important to identify the determinants of FDI, so that policies are formulated accordingly and they lead to incremental 
investment. Apart from the conventional determinants of FDI, this study focuses on the role of fiscal policy variables in influencing FDI. With a view to provide a conducive environment to foreign investment, many countries, including India, have redesigned their tax systems to make them internationally competitive. Bilateral tax treaties are a part of this exercise to alleviate the problem of international double taxation. Another important fiscal policy variable is the proportion of government expenditure that is developmental in nature.

With the help of principle component regression we have estimated a panel equation with the Least Squared Dummy Variables (fixed effects model) approach. The determinants which have emerged as significant are FDI openness and infrastructure. The FDI openness variable is significant and has a positive sign. Thus, a more liberal and open FDI policy contributes to more FDI inflows in the economy. The coefficient for infrastructural variable is also positive and significant, thereby implying that a modern and well-laid out infrastructure attracts FDI into an economy. Our variables of interest, that is, the fiscal policy variables turn out to be insignificant. Thus while a competitive fiscal policy may facilitate operations of business, it is still not a prime consideration in investment decisions.

\section{References}

Altshuler, Rosanne, \& Fulghieri, Paolo. (1994), incentive effects of foreign tax credits on multinationals. National Tax Journal, June, 47(2), 349-61.

Alworth, Julian S. (1988), The Finance, investment and taxation decisions of multinationals, Oxford: Basil Blackwell.

Auerbach, Alan J., \& Hassett, Kevin. (1993). Taxation and foreign direct investment in the United States: A reconsideration of evidence. In Alberto Giovannini, R. Glenn Hubbard, \& Joel Slemrod eds., Studies in International Taxation, (pp.119-48), Chicago: University of Chicago Press.

Boskin, Michael J., \& Gale, William G. (1987). New results on the effects of tax policy on the international location of investment". In Martin Feldstein (Ed.), The effects of taxation on capital accumulation, (pp.201-19), Chicago: University of Chicago Press. 
96 | VISION: Journal of Indian Taxation

Clark, W.S. (2000). Tax incentives for foreign direct investment: Empirical evidence on effects and alternative policy options. Canadian Tax Journal, 48.

Cummins, Jason G., \& Hubbard, R. Glenn. (1995). The tax sensitivity of foreign direct investment: Evidence from firm-level panel data. In eds. Martin Feldstein, James R. Hines, Jr., \& R. Glenn Hubbard (Eds.), The Effects of Taxation on Multinational Corporations, (pp. 123-52), Chicago: University of Chicago Press.

Devereux, Michael P., \& Freeman, Harold. (1995). The impact of tax on foreign direct investment: empirical evidence and the implications for tax integration schemes. International Tax and Public Finance, May, 2(1), 85-106.

Gropp, R. \& Kostial, Kristina. (2001). FDI and corporate tax revenues: Tax harmonization or competition. Finance and Development, June, 10-13.

Hartman, David G. (1984). Tax policy and foreign direct investment in the United States. National Tax Journal, December, 37(4), 475-87.

Hartman, David G. (1985). Tax policy and foreign direct investment. Journal of Public Economics, 26(1), 107-21.

Root, F.R., \& Ahmed, A.A. (1978). The influence of policy instruments on manufacturing direct foreign investment in developing countries. Journal of International Business Studies, 9(3), 81-93.

Scholes, Myron S. \& Wolfson, Mark A. (1991). Multinational tax planning. In Taxes and Business Strategy, Englewood Cliffs, N.J.: Prentice Hall.

Shah, Anwar, \& Slemrod, Joel. (1991). Do taxes matter for foreign direct investment. World Bank Economic Review, September, 5(3), 473-91.

Slemrod, Joel. (1990). tax effects on foreign direct investment in the United States: Evidence from a cross-country comparison. In A. Razin \& J. Slemrod (Eds.), Taxation in the Global Economy, Chicago: University of Chicago Press. 
Snoy, B. (1975). Taxes on Direct Investment Income in the EEC: A Legal and Economic Analysis, New York: Praeger.

Summers, Lawrence H. (1981), Taxation and corporate investment: A q-theory approach. Brookings Papers on Economic Activity, 1, 67-127.

Sury (2003). Tax Sensitivity of Inbound Foreign Direct Investment: The Indian Experience. M. Phil. Dissertation submitted to the Department of Commerce, Delhi School of Economics, University of Delhi.

Weinstein, David. (1996). Foreign Direct Investment and Keiretsu: Rethinking U.S. and Japanese Policy. National Bureau of Economic Research Working Paper No. 5612, June, p. 33.

Yinusa, Olalekan. (2013). Fiscal Incentives for FDI and Infrastructure Development: Economic Diversification Options for SADC Countries, African Finance Journal, 15(1), 13-35.

Young, Kan H. (1988). The effects of taxes and rates of return on foreign direct investment in the United States. National Tax Journal, March, 41, 109-21. 